\title{
The New Face of Abuse?: Questioning the Fall of the Father and Assessing the Child Exploitation in Deborah Moggach's Porky
}

\author{
Poulomi Modak \\ Ph.D Scholar (JRF), Department of English, Cooch Behar Panchanan Barma University, \\ West Bengal.Email: poulomimodak1992@gmail.com
}

\begin{abstract}
In contemporaneous world child sexual abuse is possibly the most heinous kind of child exploitation; therefore, continuous dialogue and discourse regarding the child sexual abuse should be given the primordial prominence in order to be well aware about and thereby engage with possible measures against this monster in the closet. It is in this context that the paper attempts through a detailed and critical analysis of Deborah Moggach's controversial novel Porky to make a reading of the narratives of pain, sufferings, and trauma inflicted upon the 'abject' body. Further, the novelist has incorporated the havoc of non-consensual incest which concomitantly attributes the novel as a site for insightful discussion. The proposed article, therefore, interrogates family as a possible locus of sexual exploitation of the children. This reorientation of family as a disintegrated entity eventually brings forth the question of victim's rehabilitation. Extending this, the paper finally argues any possible healing of the oppressed body.
\end{abstract}

Keywords: abusive father, body shaming, child molestation, non-consensual incest, psychological trauma

"Stories are a different kind of true". (Donoghue, 2010, p. 71)

The temporal frame between 8os and 9os of twentieth century England witnessed an unprecedented acceleration in child sexual exploitation, female abuse, and gender violation. The contemporary literature of trauma unhesitantly contextualised these issues and thus, embarked a point of radical departure from the general responses to the postmodern scepticism and relativism which primarily amplified Trauma Studies as a different field of discourse. Extending this, Deborah Moggach's novel Porky (2004), first published in 1983, provides a sensitive rendition of a traumatised self that bears an eternal conflict within the abused body; largely because of the "unnatural union" (Archibald, 2001, p. 146) between the 'fallen' father and 'deceived' daughter. The afflicted body, in this sense, is a metaphorical representation of the horror of non-consensual incest. Incest, the 'taboo', has always been prohibited in most of the modern societies with few exceptional cases, since the time immemorial on various normative grounds. Any form of incest is always "prevented" (Shepher 1983: 34) and "prohibited" (Shepher 1983: 34) by what Freud termed as the "collective mind" (Freud qtd in Shepher 1983: 136) with a deliberation for preventing the collective guilt. The restrictions on incestuous sexual activities find its analogy within sociological, religious, political, psychological, and anthropological parameters; but what seems rational as a cause of this prohibition is the scientific reasoning of inbreeding as a consequence of incestuous sexual relationships and consanguinity. This socially imposed constrain is structured in order to preserve the sanctity of family which is by common consensus "the strongest foundation of the

(c) AesthetixMS 2020. This Open Access article is published under a Creative Commons Attribution Non-Commercial 4.o International License (http://creativecommons.org/licenses/by-nc/4.o/), which permits non-commercial re-use, distribution, and reproduction in any medium, provided the original work is properly cited. For citation use the DOI. For commercial re-use, please contact editor@rupkatha.com. 
social order" (Shepher, 1983, p. 140). Ironically though, the text which is taken into consideration for the context discloses that within the familial space the iota of disciplinary modalities had been discarded and quite shockingly the incest occurrence has been accentuated. The taboo of incest which remained as an "open secret" (Sacco, 2009, p. 2) in familial spaces for so long has suddenly been disrupted by the new negotiations of psychoanalytic studies to dismantle the fatherdaughter incest and the horror of child sexual exploitation resulting out of such traumatic experiences.

Family as a concept has undergone paradigm shift as it was primarily meant to be the quintessential idea of the safest resort for its inhabitants that eventually transcends as a locus of disorder and decay in the social milieu of postmodern worldview. Porky is an astounding illustration of such unusual treatment of family disintegration that exposes "the exploitation of children and the corruption of parental love" (Herman, 2000, p. 4). The inherent disturbance within the family advances the appalling narration of "consummated father-daughter incest" (Archibald, 2001, p. 147) and attributes a plethora of questions with no certain answer. Maisch (1972) appropriately observed that incest is not a cause of family disintegration but a symptom of a "disturbed family order" that already exists (p. 145). Likewise, the 'fallen' father's repugnant advances "of his relationship with his daughter" (Archibald, 2001, p. 146) concurrently epitomise the distortion and deception inherent in the family structure. It was a sheer shock to the child, Heather, that within the cosy privacy of her own family the father behaved as the most offensive sexual predator. It is easily discernible that a child at that tender age of ten is incapable of fathoming any form of physical abuse which incites her to bear with the enormous pain that finally develops in her mature years as an everlasting nightmare. The physical exploitation of the child initiated when her mother was expecting her second child, the brother of Heather: "It all started when Teddy was born" (Moggach, 2004, p. 26). It is then the absence of the mother that acted as a kind of catalyst for the father who by his disgrace has already descended as 'fallen'. The author minutely describes the first instance of the father being an abuser against which the daughter is manifested as a baffled creature by such incomprehensible turn of the events:

He squeezed me tighter. I could hardly breathe. "Give us a kiss," he said. "A kiss for your Dad". I removed my face from his ear and kissed his cheek, as I always did. Then I drew away but he pulled me back. He kissed my lips. His moustache tickled. Then, with his lips he opened mine. His tongue slid into my mouth, warm and wet. Inside it moved around ...It felt uncomfortable. His mouth was bigger than mine; he was going to swallow my face...His mouth stayed glued to mine, his nose digging into my cheek. His hands rubbed up and down my front. (Moggach, 2004, p. 30-31)

Heilmann and Llewellyn (2010) define that by speaking about the stories of traumatised past or by bearing the testimony of the traumatic experiences, the survivors come in terms with their irrecoverable wounds and consequently possibility lies in their progress towards healing (p. 37). Therefore, she, the victim, is in dire need of a confidante to whom she can disclose the truth that can hasten her recovery from the awful existence. But this disclosure becomes terrifyingly impossible for most of the abused bodies. Similarly Heather, the 'deceived' daughter in the novel, is in need of a silent listener to her endless suffering and a "witness to the molestation, not an interpreter of it" (Rachman and Klett, 2015, p. 13). As for the question of the mother's responsibility, the literal or psychological absence of the mother figure does seem to be a reality in many families where incest develops. The maternal absence, in this case the psychological deprivation of a supportive mother, affects the girl child's convalescence to the large extent. The separation of the child from the mother constricted any possibility of emerging the mother as the 
child's most trusted confidante. Herman in her study on father-daughter incest especially emphasises the need of the mother in a daughter's life. Herman points out the lack of motherconfidante as a significant stimulant in increasing the risk of girl child abuse: "The lack of a strong, competent, and protective mother does seem to render girls more vulnerable to sexual abuse. Maternal disability of any sort represents a significant family stress and is perceived by all family members as a deprivation" (2000, p. 49). In the novel, the mother's constant absence affects Heather profoundly as she is forced to be "closer" (Moggach, 2004, p. 18) to her father emotionally as well as physically. The mother's reluctance to create an affectionate bond with her daughter or with her children is a rare case. In her retrospection the daughter could not search for a single fond memory of her playing with or cuddling her mother: "As I said, she wasn't one for showing affection [. . .] She never hugged me [. . .]" (Moggach, 2004, p. 18) or "I don't remember her playing with me" (Moggach, 2004, p. 21). This fear of isolation and undesirability compel the daughter not to revolt against the abusive father's non-consensual intimacy with her. Heather recollects this fear of seclusion with an anxious presupposition that "if I'd stopped him, he might have stopped loving me" (Moggach, 2004, p. 90) and "nobody would" (Moggach, 2004, p. 90). According to Kelleher, such indifference towards the motherly responsibilities is an indication of an "utter failure or collapse of primal shelter, of the mother's inability to nourish or protect her child" (1997: 7).

The mother's insouciance is the consequence of the collective indifference towards such unusual physical abuse as the awareness analogous to the child exploitation is very limited. The lack of a sensitive approach firstly to accept the occurrence of child sexual abuse and then to sympathetically examine this bleak aspect of human experience is rampant even to this day. Rachman and Klett (2015) identified the "emotional blindness" (p. 1) as one of the prominent causes of this lack of knowledge regarding the traumatised survivors. The difficulty to accept the idea of "parental evil" (Rachman and Klett, 2015, p. 7) is such a critical problem in any social structure that any exploitation incorporated by either of parents or both the parents is primarily discarded as "crazy ideas" (Rachman and Klett, 2015 p.6). All loving and caring nature is intensely attributed to the image of the parents that any form of objectionable statement against them rarely alarms the listeners. Moreover, the rigid denial of the abusive father intensifies and as well as prolongs the oppression. Herman explains this tendency: "For the father, the disclosure is likewise a threat to his entire way of life. He stands to lose not only the sexual contact he craves, but also his wife, his family, his job, and even his liberty" (2000, p. 132). Withstanding this overwhelming threat, the sadistic father generally adopts the mechanism of outraged denial. Correspondingly, the refutation is the reciprocal response from the father in the novel as soon as he finishes his abominable act. He repetitively insisted that he "meant to be affectionate ... didn't mean no harm" (Moggach, 2004, p. 32), again "I didn't mean it, honest I didn't" (Moggach, 2004, p. 32). Whether it is his sense of guilt or his sincere apology, the father pleads: "Come and forgive me [...] Let's you and me forget it [. . ] Nothing happened [. . ] OK" (Moggach, 2004, p. 32). The father's apology followed by the instruction to forgive and forget implies little impact upon the tender soul who by now understands that "the little scene" (Moggach, 2004, p. 34) is potential enough of making anyone uncomfortable than the "shock-horror stories" (Moggach, 2004, p. 34) in the fictions.

Foucault in the article "Nietzsche, genealogy, history" defines that the body is "the inscribed surface of events (traced by language and dissolved by ideas), the locus of a dissociated self (adopting the illusion of a substantial unity), and a volume in perpetual disintegration" (Foucault, 1986: 83). Extending Foucault's vision of body as a locus manifesting the power dynamics, it is easily perceptible that the suppressed body of Heather as a 'site' as well as a 'locus' 
of myriad forms of power politics in the socio-cultural paradigms exposes the 'events' that always bear the testimonials for women sufferings and suffocation. The consciousness about her body and thereby rejection of the body begin as soon as Heather enters her adolescence. The unwanted spots and lumps are consciously jilted and considered as a betrayal to the body: "It's betrayed you, hasn't it, sprouting spots and thickening, lumpily, just where you don't want it to thicken" (Moggach, 2004, p. 77). Body shaming a term that is often used in contemporaneous times has its linkage to the story while the child has been harassed on the ground of her chubby appearance. She remembers that she was "a lump of a girl . . . [and] no wonder the piggy name stuck" (Moggach, 2004, p. 9; improvisation mine). She maintains the personal hygiene regime strictly as opposed to the filth of sty to which she is often compared: "I was one of the cleanest people in the school. If I ponged of anything, it was talc. I used to bring the tin in with me. I'd go into the toilet and take off my socks and sprinkle my feet" (Moggach, 2004, p. 9). Though she is the cleanest externally, she assumes her "inside [. . . ] was dirty" (Moggach, 2004, p. 9). This "abjection" (Butler, 2004, p. 149) to the bodily integrity is further intensified with her sense of "guilt" (Moggach, 2004, p. 77). She realises quite unfortunately that the body she carries does not belong to her exclusively; she is no longer the sole possessor of her bodily autonomy: "I carried this body around but it didn't belong to me anymore [. . .] I wouldn't be Heather any more" (Moggach, 2004, p. 78). The gradual awareness of the guilt makes things clearer to her as she eventually comprehends that "it's his fault too" (Moggach, 2004, p. 83; emphasis original). The complication escalates in her adolescence when she further drowns into the dungeon of frustration and trauma. She reveals: "It wasn't until I was thirteen, and Dad and I had been having sexual intercourse for a year, that I let myself begin to realize what was happening" (Moggach, 2004, p. 81). Her inevitable repudiation certainly could not safeguard her "body [which] had been violated" (Moggach, 2004, p. 84; improvisation mine); or restrain her father from being a disgusting paedophile.

Instead of a progression towards recovery, the undesirable yet inevitable consequence for most of the survivors is their becoming hysteric - suffering from "traumatic hysteria" (Kaplan, 2005, p. 26). Freudian interpretation of hysteria is effective in dismantling the case of such abused daughter. The sexual abuse or physical exploitation as a recurrent motif behind the arousal of hysteria has as its explanation in the Freudian essay of "Heredity and the Aetiology of the Neuroses". In this context, Freud (1962) explains the historicity of the sexual victimisation within the framework of the unconsciousness: "The subject has retained an unconscious memory of a precocious experience of sexual relations with actual excitement of the genitals, resulting from sexual abuse committed by another person; and the period of life at which this fatal event takes place is earliest youth - the years up to the age of eight to ten, before the child has reached sexual maturity" (p. 154). Similarly Heather develops the symptoms of hysteria as an aftermath of prolonged repression. The trauma causes her to believe that she is only capable in forming relationships which are short-lived and only maintained on sexual promiscuity. This inadequate self-confidence in her own integrity leads her where an unavoidable tendency to prostitution emerges. The irrecoverable destruction of trust drives the daughter in becoming mentally unstable, schizophrenic, hysteric, or in extreme cases converting her to be a prostitute. Herman interprets this fatal probability in which the father coerces the daughter to make stances unwillingly: "The actual sexual encounter may be brutal or tender, painful or pleasurable; but it is always, inevitably, destructive to the child [ . . . In so doing, he destroys the protective bond between parent and child and initiates his daughter into prostitution" (2000, p. 4). The daughter in the novel eventually engulfs further pangs of punishments for the crimes she has never committed by secluding from the entire extrinsic world, avoiding any possibility towards progress, and ultimately rejecting the brighter side of life. Heather's turning into prostitution and 
later renouncing the marriage proposal of Ali, who was the "only person who's ever tried" (Moggach, 2004, p. 233) to love her, manifest that the prospect of healing is a utopic vision for most of the victims. Therefore, Heather suffers eternally.

Remarkably enough, Trauma Studies in Postmodern fiction attempts to verbalise and thereby heal the collective traumas of the lost past and throbbing present and as well the personal traumas exerting on racially, sexually marginalised groups. However, this theory, as expressed earlier, extended beyond its source of inception in the field of humanities with the exceptional hike of heart-rending revelations of child abuse in the 1980 on and 1990s. Incest, as an instrumental force in inflicting irreducible trauma within the victims, undoubtedly has long been one of the brutal expressions of patriarchal domination and male sexual assault which is now as Archibald envisions "challenged" (2001, p. 4) within a plethora of micro-narratives. Feminists' explanations posit such suppression within the context of patriarchal power politics. The body of the female is tortured and tormented in order to satiate the male desire of sexual violence. Vikki Bell elaborates this phenomenon in the introductory chapter:

Feminists argue that incest is a form of sexual abuse, one that is perpetrated mainly by men, and one that has to be understood within the context of a society in which men are able to exercise power over women and children in a sexualised way. The feminist analyses place incest within the range of male violence, understanding incest on the model of the feminist understanding of rape. (1993, p. 3)

Indeed, incestuous abuse is based on the patriarchal family structure; therefore, the prevention of child abuse requires a radical change in the structure of the family. The idea of family demands for a drastic transformation. Beauvoir's insistence of an alteration of this rigid patriarchal world with an "androgynous world" (1956, p. 682) anticipates a pathway towards a 'better' world where "the child [. . .] would not be oriented towards passivity" (1956, p. 682); where any such deceived daughter, like Heather, would not be "a victim of circumstance" (Moggach, 2004, p. 235).

Emma Donoghue's neo-Victorian fiction The Wonder which incorporates the trajectory of a similar 'victim of circumstance' perfectly encapsulates that "every disease had a story with a beginning, middle, and end" (2016, p. 303). The detailed exposure of the abused body since the inception of its struggle to the harrowing end delineates how the seclusion from the society leads the victim to an irrecoverable state of being. Further, the instance of forceful incestuous relationship is interrogated as the source of conducing inexplicable pain within the participant involved; as the survivor grapples helplessly amidst a fiasco of social structure which cannot ensure rehabilitation for the ailing body that pathetically obliterates any iota of amelioration of the victim. The confinement of the incestuous relationships into a "taboo, nonexistence, and silence" (Foucault, 1998, p. 5) is prevalent in common discourses. The silent endurance of the incest motif can be understood as an integral dynamic of trauma oozed out from these destructive desires. Margaret Kelleher points out that "such a silence [. . .] may denote depths of pain, of shame and of guilt on the part of those who survived" (1997:4). The brooding silence is then the metaphor for the 'unspeakable' tendency of the incestuous relationships. Porky, thus, is a scathing criticism of the perpetual universal silence and collective indifference towards the child exploitation brooding over the ages. These heart-wrenching revelations of shocks and trauma are influential since the actual occurrence of sexual abuse is often a painful experience. Therefore, a pragmatic study of such abusive encounter is effective in catering a sensible outlook on the literature of trauma alluding to the painful confessional narratives. 


\section{References}

Archibald, Elizabeth. (2001). Incest and the Medieval Imagination. New York: Oxford University Press.

Beauvoir, Simon de. (1956). The Second Sex. Translated by H. M. Parshley. London: Jonathan Cape.

Bell, Vikki. (1993). Interrogating Incest: Feminism, Foucault and the Law. London: Routledge.

Butler, Judith. (2004). Undoing Gender. London: Routledge.

Donoghue, Emma. (2010). Room. London: Picador-Pan Macmillan.

—. (2016). The Wonder. London: Picador.

Foucault, Michel. (1986). 'Nietzsche, genealogy, history', in P. Rabinow (ed.) The Foucault Reader (pp 76100). Harmondsworth: Peregrine.

-. (1998). The History of Sexuality 1: The Will to Knowledge. Translated by Robert Hurley. London: Penguin Books.

Freud, Sigmund. (1962). Heredity and the Aetiology of the Neuroses. Standard Edition (pp 143-156). Translated by James Strachey. London: The Hogarth Press.

Heilmann, Ann and Mark Llewellyn. (2010). Neo-Victorianism: The Victorians in the Twenty-First Century, 1999-2009. New York: Palgrave Macmillan.

Herman, Judith Lewis. (2000). Father Daughter Incest. Cambridge: Harvard University Press.

Kaplan, E. Ann. (2005). Trauma Culture: The Politics of Terror and Loss in Media and Literature. New Brunswick : Rutgers University Press.

Kelleher, Margaret. (1997). The Feminization of Famine: Expressions of the Inexpressible? Durham: Duke University Press.

Maisch, H. (1972). Incest. New York: Stern and Day.

Moggach, Deborah. (2004). Porky. New York: Random House.

Rachman, Arnold W. and Susan A. Klett. (2015). Analysis of the Incest Trauma: Retrieval, Recovery, Renewal. London: Karnac Books Ltd.

Sacco, Lynn. (2009). Unspeakable: Father-Daughter Incest in American History. Baltimore: The Johns Hopkins University Press.

Shepher, Joseph. (1983). Incest: Biosocial View. New York: Academic Press.

Poulomi Modak has completed her MA in English with a specialisation in Indian English Literature in 2015 from Cooch Behar Panchanan Barma University (CBPBU), West Bengal. She has qualified SET in 2015, UGC NET in 2015, and CBSE NET with JRF in 2016. She was a full-time Contractual Assistant Professor in the Department of English, CBPBU for two consecutive years. Presently she is a Doctoral Fellow (JRF) in the Department of English, CBPBU. Her research orientation is incestuous relationships in Modern literature. She can be reached at poulomimodak1992@gmail.com. 